\title{
Identity and Peace: Reconfiguring Conflict Resolution in Africa
}

\section{Gerard Hagg and Peter Kagwanja}

\section{Abstract}

The emergence of intra-state wars based on identity requires a reconfiguring of existing conflict resolution mechanisms. The article recognises the limitations of liberal peace models originally configured to deal with inter-state conflicts, but increasingly applied to inter-ethnic conflicts with limited success and often disastrous effects. The article argues for the reconceptualisation of identities as building blocks of sustainable peace, justice and reconciliation. The article also calls for the recognition of the role of regional peace and security mechanisms in conflict resolution, as far as possible the use of traditional justice mechanisms, especially in the context of increasing state failure on the continent. The article cautions against enthusiastic embrace of international justice mechanisms that may sometimes create stumbling blocks to peace and reconciliation. Rather the article suggests nuanced interventions in identity-based conflicts that reconcile democracy and justice, guaranteeing the rights of both majority and minority groups.

* Dr Gerard Hagg is a senior researcher in the Democracy and Governance Research Programme of the Human Sciences Research Council (HSRC), South Africa. Dr Peter Kagwanja is executive director (acting) and research director of the Democracy and Governance Research Programme. The authors are indebted to the HSRC which provided funding for the research towards this article. 


\section{Introduction}

The dual processes of market liberalisation and democratisation in the 1990s substantially weakened the post-colonial state, ushering in new forms of violence and disorder as the hallmark of the post-Cold War Africa. These new patterns of conflicts have been described as 'internal' or 'civil wars' largely because they involved a clash of identities such as ethnicity within the state - although they often overflowed across national borders and affected the neighbouring countries: the 'bad neighbourhood' syndrome (Young 2004:44). It is true, as the former Secretary-General of the United Nations, Kofi Annan (1998:3), argues, that the 'sources of conflict in Africa reflect... diversity and complexity'. Africa's ethnic diversity has been blamed for the escalation of violent conflict and the implosion of the state. In the post-Cold War era, such identities as Tutsi, Croats or Hindu have appeared armour-plated in deadly combats that have mirrored Samuel Huntington's clash of civilisations on a global scale (Huntington 1996; Ross 2000; Deng 2005; Horowitz 1985). Although ethnic identity on its own does not necessarily cause or perpetuate violent conflict, it has become 'a sort of universal shorthand that marks a host of much more complex issues of identity and difference' (Broch-Due 2005:6; Khazanov et al 2004).

Thus, even as analysts confirm the importance of identity in what Mary Kaldor calls the 'new wars', they have also underscored the importance of the specific cultural, social, economic and environmental conditions that transform identities into instruments of conflict (Kaldor 1999; Richards 2005). Braathen and others (2000) refute the importance of ethnicity in violent conflict, as reflected in the title of their publication: Ethnicity kills? A dominant explanation, the 'greed-and-grievance' thesis, has illuminated the link between the escalation of identity-based civil conflicts and the unfolding 'war economies' which feed and fuel them (Collier \& Sambanis 2005; Elbadawi \& Sambanis 2000). But the thesis overstates its case, committing the same old sin of perpetuating stereotypical and banal views of Africa as being driven by the 'politics of the belly' (Bayart 1993). 
Despite this linking of ethnic entities with violent conflict, it has become clear that identities have a role to play in conflict resolution. Organisations like UNESCO (2005) and the African Union (2005) have embraced cultural diversity and the expression of different identities as important assets in peacemaking and nation building. Indeed, authors like Tan celebrate the diversity of identities as an asset in the re-engineering of the civic order (Tan 2006). Ethnicity is not in itself a venal or negative force. The historian John Lonsdale (1994) has distinguished between 'moral ethnicity' and 'political tribalism,' capturing the benign and negative forces of ethnic identities, respectively. In this regard, social movements have been acknowledged as potential counter-hegemonic forces to the centralising and domineering forces of the secular nation-state (Eyo 1999). In many respects, ethnic movements have oftentimes localised struggles for citizenship in ways that have created moral communities, mobilised resources and broadened the space for cultural citizenship.

This article argues that while identity has been at the heart of violent conflicts in Africa, sustainable peace on the continent depends on the reconfiguring of identities as the basis of conflict resolution and postconflict reconstruction models. This argument is made in six stages of which the first four discuss the broader picture of violent conflict, while the last two deal with peace making. The first section situates the concept of identity within the broader context of the crisis of the post-colonial state in Africa. The second part examines the role of identity in violent conflict in Africa from the 1990s, while the third section discusses civil conflict as a response to the undemocratic state after 1990. Section four highlights the role of globalisation in conflict. Section five provides a critique of the dominant models of peace and conflict resolution which are largely informed by the liberal orthodoxy. Finally, the article explores the conditions under which identities can be transformed into mechanisms for conflict resolution and peacemaking in war-torn ethnically-divided societies. At the heart of the African crisis is the failure to bring identities to the centre of democratisation and institution building processes, both before and after conflict. 


\section{Identity and the 'new wars'}

Following the end of the Cold War, Africa became a theatre of violent conflicts from Burundi to Liberia, the Democratic Republic of the Congo to Sierra Leone, Somalia to Rwanda and Guinea to Sudan. The indelible mark of the new wars is that they are linked to identity, particularly ethnic identity. While there are many identity markers such as race, nationhood, kinship, class, religion, language, gender, age, geographic location, cultural preferences, and occupation - such as military function or herders and tillers - by and large ethnicity is identified as the dominant axis about which conflicts have revolved.

Three arguments have been made to explain the new patterns of violence. To begin with, this violence is seen as senseless or a return to barbarism (Mamdani 2002). With the emergence of pluralist democracy, this violence has been seen as a ploy by the incumbents to undermine democracy and perpetuate themselves in power (Kagwanja 2001). Thirdly, some scholars view the explosion of ethnic-based violence in countries like Rwanda as a manifestation of the brutal legacy of manipulation of ethnicity in the colonial past now returning to haunt the post-colonial state (Mamdani 2001).

Trying to make sense of this violence, Kaldor (1999) argues that the new conflicts are not wars in the modernist sense between states or organised political groups for political ends. Rather, they are connected with the resurgence of identity politics after the collapse of the Berlin wall. In this regard, primordial identities have pursued claims to power within the arena of the modern nation-state. The ubiquity of identity wars is based on the fact that ethnic identity is indeed particularly strong in traditional societies - embodying the deeply-embedded sense of belonging to a group with unique identity markers, such as myths of common ancestry, shared memories, cultural values, traditions and symbols, and ownership of territory (Endalew 2002). 
However, the accent on ethnicity as a cause of conflict is problematic in at least two ways. First, ethnic identity does not sufficiently explain communal wars. Some homogeneous nations like Somalia have been engulfed in civil war while many heterogeneous societies live in peace, as Osman argues in this issue (2007). Further, the so-called African traditional identities are often recent constructions, either by colonial powers or by their post-colonial successors, resulting in mythologies of Africanist cultures (Banégas 2006; Bayart 2005). Why then has the ethnic identity become so combustive?

Attempting to account for the implosion of ethnic-based violence, Arjun Appadurai (1998) linked the preponderance of identity conflict to the forces of globalisation, noting that ethnic violence is deeply rooted in the uncertainties, anxieties, disillusions and chaotic environments created by economic globalisation. Africa's new wars neither corresponded to Frantz Fanon's (1967) 'humanizing native violence' against an equally violent colonial state nor to Hannah Arendt's (1975) 'dehumanizing' state violence against its citizens typified by the Nazi Holocaust or, more recently, ethnic cleansing in the now defunct Yugoslavia. The violence is non-revolutionary and 'non-liberative'.

When they came face to face with this new form of violence, many analysts understood it as a new trend by the leaders of the one-party vintage to resort to recruiting surrogates and clients to organise violence against rebellious citizens. Mohamed Salih (1989) unveiled how the Sudanese state recruited tribal militias to terrorise civilian populations in a move that contributed to the 're-tribalisation' of politics. The use of tribal authorities as agents of political violence became widespread in countries as diverse as Nigeria, Cameroon, Kenya, Malawi and South Africa.

Nevertheless, this violence was more complex than simply being one-way violence by the state against its citizens. Intellectuals and publics used the term 'nationalism' to describe the sensibilities and violence linked to culture, ethnicity, religion and other negative forces of society (Anderson 2004). As the historian Eric Hobsbawm has noted, nationalism in the new 
age has acquired a reactionary character in contrast to that of the emancipatory nationalism that was associated with wars of liberation from colonial imperialism across the world. Bruce Berman (1998) christened this new form of nationalism as 'uncivil nationalism', largely because it is about identity politics and sensibilities or contestation for power on the basis of identity labels. In this regard Kaldor (1999) concludes that the 'new wars' that have ravaged Africa lack 'geographical or ideological goals of earlier wars' and are largely 'internal or civil wars'.

Yet, these new patterns of violence are not simply 'internal' or civil wars as Kaldor and others posit. They are part of 'regional conflict complexes' or formations that link local and global spaces, revealing the ugly underside of globalisation. Ethnic militias, combatants or bandits feed into 'economies of war' which are inextricably connected to globalised illegal economic networks and contrabands in precious metals, gemstones, drugs, guns and human trafficking.

At another level, these wars are not simply about war economies. They are also linked to complex proxy wars involving regional powers. The war in Somalia, for example, has also come to be linked to the longstanding conflict between Ethiopia and Eritrea, with both protagonists underwriting and backing rival forces within the country. Moreover, as the case of America's involvement in Somalia allegedly to rout out the Union of Islamic Courts' fighters shows, what are viewed as internal wars are also linked to the 'clash of civilisations' which now defines the parameters of the global 'war on terrorism'. This broad context must be borne in mind when seeking durable solutions to the emerging culture of ethnic violence and state failure.

\section{Identity and the African state}

Historical analyses of conflict enchant the pre-colonial period as the golden era of identity relations, pointing to the low politicisation of ethnic or other identities in society. Mixing of identity groups often occurred during trade, wealth and provision of skills (Bayart 2005:92-96). But the 
distinct mark of pre-colonial African societies was not the absence of multiple identities or conditions that could ignite conflict. Rather, it was the absence of the elevation and politicisation of a single identity - ethnicity, clan, gender or age gap.

Political 'tribalism' as opposed to 'moral ethnicity' which can form the basis of a civic order, is rooted in colonial politics. Part of Africa's problem is what Peter Ekeh (1975:92) identified as the dichotomy between civic public and the primordial public, the former perceived as an amoral zone of rights and the latter as moral and governed by customs. Africa is still struggling to bridge the gap created by these bifurcated spheres inherited from the colonial society, which has produced two patterns of rights and obligations.

Picking from Ekeh's point, Mamdani argues that the ethnicisation of politics started with the construction of ethnicity as a legal entity that was elevated over otherwise fluid and loose characteristics of populations. This process turned race and tribe into fixed denominators in the colonial legal project (Mamdani 2002). Ethnicity became axial to the colonial divide-and-rule device used for the purpose of political control, enforcement of taxes and extraction of wealth (Broch-Due 2005; Rubin 2006). The colonial state drove a wedge between ethnic groups by giving preferential treatment to some identity groups through appointments of local authorities or administrative staff in the colonial offices. For example, the Belgian and French ascribed the Hamitic 'race' identity to the Tutsis in Rwanda as against the 'Bantu tribal' identity of the Hutus. This flawed classification laid the foundation for ethnic rivalry and conflict which would culminate in the 1994 genocide (Prunier 1997). The colonial manipulation of ethnicity bequeathed Africa's post-colonial societies with the polarities of settler (migrant) and native (indigenous) categories. These have become the axis about which ethnic violence in Rwanda or more recently in Kenya rotates (Mamdani 1996:201).

Africa's post-colonial states inherited these ethnic stereotypes and divisive patterns of power between and within specific ethnic identities, thus 
sowing the seeds of competition and conflict along ethnic fault-lines. It did not help the matter that many post-colonial patrimonial elites continued this legacy of divide-and-rule to protect their power. The rise of one party states or no-party military systems enabled these rulers to keep the lid on the simmering inter-ethnic rivalry and animosity, but the democratisation process and economic reforms associated with the Structural Adjustment Programmes 'erased the earlier post-colonial state's claim to unencumbered hegemony' (Young 2004:43). The authority of the state also increasingly came under attack during the era of globalisation. As Appadurai (1998) correctly observes, globalisation has fostered uncertainties and inequalities that have reinforced primordial sensibilities and recidivist ideologies, inspiring the atomisation of political processes. The decline of the hegemonic state and socio-citizenship opened the vent for rival ethnic groups to challenge the authority of the central state and the ruling elite.

\section{State crisis and new patterns of civil conflict}

The crisis of socio-citizenship and the challenge to central authority by peripheral forces resulted in Africa's new patterns of civil conflict. The vision of civic citizenship based on a multi-ethnic nation-state that punctuated the post-colonial nation-building project across the continent is everywhere being challenged by notions of localised citizenship based on ethnicity. From the outset, civic citizenship was expected to be inclusive in regard to political power, decision-making and access to economic and other opportunities. However, the prevalence of patrimonial systems led to the exclusion of 'outsider' identities, and to unequal development and widespread disaffection.

The prevalence of patrimonial systems based on ethnic identities also tended to exclude rival identity groups, placing ascribed barriers to their upward mobility (El-Battahani 2007). Thus what were essentially cultural identities became transformed into political identities. Through 
this process, ethnicity was animated into a political force, with ethnic citizenship becoming a counter-force to civic citizenship.

With the collapse of the nationalist consensus that ushered Africa into independence, the one-party state was widely imposed across the continent as a visible symbol of 'unity-in-conformity' anchored on the hegemony and coercive capacity of a single identity group or a coalition of several identity groups. Corruption and lack of accountability became the norm as pressure intensified on public servants to use their civic positions to satisfy their own imperatives of sharing resources with members of their larger communities. With no other recourse, those communities that felt excluded from the state and discriminated against by the dominant group often resorted to violent tactics. This happens especially when the stakes for survival are heightened by democratic competition diminishing economic opportunities, livelihoods and increasing poverty.

This dire situation is complicated by what has been characterised as the predatory nature of the African state. This has happed when the dominant elite appropriates and personalises the state, using it as an instrument of self-enrichment and of rewarding ethnic kith and kin and clients. In the ensuing neo-patrimonial arrangement, the identity of the party and the leader appears as a giant octopus swallowing other identity and social groups such the intelligentsia, the working class, women, businessmen or youth (Richards 2005).

Nonetheless, predation has not been limited to the dominant party and ethnic group. Segments of the counter-elite (elite not in power) also seek to win control over the state as a prize to gain access to the privileges of power. In some cases, where counter-elite formations have failed to seize power in the context of a weak state, this has often resulted in the emergence of parallel centres of power based on a new social construction and identity (Biaya 2001). Many of the military coups in Africa were largely a product of this desire to win state power in an ethnically contested political terrain. Indeed, rebel movements such as those led by Savimbi in Angola and Sankoh in Sierra Leone reflected this ubiquitous 
pattern in Africa. Similarly, with the emergence of multi-party politics in many parts of Africa, opposition political parties have coalesced around their ethnic base (Prah 2004).

More often than not, the African state has been too weak and dysfunctional to act as a neutral arbiter or to enforce authority based on a common notion of civic citizenship. Its economic weakness and endemic lack of resources and infrastructure have eroded the capacity of the state to exert its control and suppress any challenge to its authority, especially by identity groups in peripheral areas which tend to back rebels (Faeron \& Laitin 2003:80). This is best exemplified by the inability of successive weak governments in the Democratic Republic of the Congo to effectively contain rebellions in parts such as the Kivu region. Crossborder ethnic identities and alliances have also tended to exacerbate the problem of central authority in the periphery areas. This is typical of the Great Lakes region where neighbouring states have hosted hostile rebel groups (Mamdani 2002).

Many of Africa's weak states are unable or unwilling to act impartially as neutral arbiters between conflicting or competing identity groups. Similarly, lack of modern institutions such as constitutions or independent judiciaries have denied identity groups of credible channels through which to address their grievances and quests for equity, fairness and justice. The only recourse is violence.

Apart from their weakness, dysfunctionality and predatory nature, African states have hosted existing regimes of resource-exploitation which have tended to transform identities into instruments of conflict. Broch-Due (2005:2) rightly notes that 'as resources dwindle and relations of wealth are reconfigured in the wake of violence, identities and ideas of belonging become the focal arenas of conflict and negotiation'. It is in this context of state failure that poverty has been identified as a cause of identity-based conflict.

But poverty in itself is not a trigger of identity-based violence. Indeed, a number of poor nations in Africa have not suffered any civil war or 
serious challenge to the state. Inequalities between and within identities as well as patterns of identity-based deprivation tend to create fertile ground for poverty as a source of conflict. Not surprisingly, most countries facing civil wars have deep levels of poverty, often affecting specific ethnic groups. Africa's army of unemployed youth have become easy recruits by rebel groups, which offer attractive promises of employment or income-generating alternatives in situations of abject poverty and powerlessness. Conversely, countries like Botswana, which have sufficient wealth, above-average income and small populations have tended to be less conflict prone.

\section{Return to barbarism or globalisation's demons?}

The crisis of the African state has been spiked by forces of globalisation, which have deepened the continents' new forms of conflict. While the expansion of globalisation was expected to open up opportunities that would ameliorate the crisis of the state, it has simultaneously globalised ethnicity and localised citizenship, creating conditions for violent conflict (Kagwanja 2003:112-152). Appadurai (1998) among others rightly traced the roots of the brutal surge of ethnic violence in Latin America, Eastern Europe and Africa to the uncertainties, anxieties, disillusions and chaotic environments created by economic globalisation. In this respect Africa's civil conflicts are not only heavily dependent on local depredation, but also on global linkages and support. It is therefore a paradox that the resurgence of 'communal violence' was viewed in liberal circles as a return of barbarism to haunt globalisation.

Logically, the forces of economic globalisation have ubiquitously tapped into the markets of anarchy within Africa's theatres of war, producing dynamics which have escalated and sustained civil conflicts. As reports by the New York University's Center for International Corporation aptly noted, conflicts in the Great Lakes region constitute a conflict complex or formation with local, regional and global linkages. 
The report concludes that:

Linkages between international corporations and the region have exacerbated conflict on a number of levels: not only do they provide financial incentives for contenders for power, but they have also employed mercenaries to provide security for commercial extractive ventures... In addition, international regulation regimes and other legal restrictions often make the black market more profitable. These restrictions provide financial incentives for cooperation to engage in business ventures with whoever controls and delivers state resources, regardless of the impact on local population or the political repercussions for the state (Kagwanja \& Ntegeye 2001:9-10).

The direct and indirect role of the forces of economic globalisation in Africa's ethnic wars also tended to transform them into 'business wars'. Africa witnessed increasing involvement of mercenary companies in civil wars in Angola, Liberia, Sierra Leone and the Democratic Republic of the Congo in ways that carry eerie memories of colonial pillage and violence. Widely cited is the role of two British mercenary companies, Sandline International and Executive Outcomes, which aided militias in Sierra Leone to secure access to mineral-producing areas in return for direct payments and commercial concessions (Storey 1999:39-56). Notably, the area controlled by Liberia's warlord, Charles Taylor, in Sierra Leone and Liberia is said to have been the third largest supplier of hard wood to France in the 1990s!

The lucrative commerce in timber and 'blood diamonds' in West African conflicts also tended to reinforce the claim that markets are capable of thriving without states at all. This view of markets in corrupt states privileges the profits of war over the human rights of the people trapped in these cycles of conflict. Weakened or eclipsed by local and regional conflicts, contemporary African states found themselves stripped of most statecraft functions and sovereignty, and increasingly under untrammelled influence by business corporations, NGOs and international aid bureaucracies' (Broch-Due 2005:3). 
African states have also found themselves becoming irrelevant in the eyes of many of their citizens as the externally imposed economic reforms whittled the ability of governments to meet the demands of social citizenship with regard to providing social infrastructure and services, such as health and education. Devastation arising from the greed of international corporations, such as Western oil companies, also undermined the livelihoods of local people, creating grievances as fertile grounds for the proliferation of militias in places like Nigeria's Niger Delta region (Akpan 2007).

Several studies point to the role of international actors in the proliferation of small arms in Africa's hotspots, which has intensified conflicts and increased tensions and deaths (IANSA/Oxfam 2007). While identity violence has tended to aid the course of globalisation in Africa in cruel ways, this linkage between localised conflict and globalisation has undermined citizenship and human rights of the African people.

\section{The liberal peace and its discontents}

The globalisation solution to localised ethnic conflicts is liberal peace. The impact of conflict resolution efforts driven by the imperatives of 'liberal peace' has been mixed and controversial (United Nations University 2007:1). The concept of 'liberal peace' is based on the Kantian notion of three pillars on which global peace rests: republican representation, an ideological commitment to fundamental human rights, and transnational interdependence (Doyle 2005:463). Liberal peace has come to embrace democracy, individual human rights, market values, the integration of societies into globalisation, self-determination, and the idea of the state and citizenship.

In a number of instances conflict resolution initiatives based on the liberal peace principles have brought an end to violent conflict and created platforms for reconciliation. South Africa's model for political settlement that resulted in the transition from apartheid to democracy 
in 1994 is hailed as a showcase of the success of liberal peace in Africa (Kagwanja 2007). Driven by the need to draw the warring parties to the negotiation table, the liberal peace model has followed a familiar, almost formulaic, path: preliminary talks ('quiet diplomacy') paving the way for formal talks; negotiations leading to a comprehensive peace agreement; establishment of a Government of National Unity (GNU) acting as transitional authority to arrange for a new constitution, and multiparty democratic elections. The role of unresolved identity grievances after the elections has not received adequate attention, making it difficult to explain implosions in countries like Kenya, previously touted as a showpiece of peace and stability. South African mediators have applied a variant of the liberal peace model with considerable success in Burundi and the Democratic Republic of the Congo. However, the application of the model in Côte d'Ivoire had dismal success. In Côte d'Ivoire, intensive negotiations under the aegis of the African Union and the UN Security Council from 2004 led to the cessation of violence, but failed to resolve the conflict. In contrast, the battlefield victory by the government of Angola following the death of Savimbi in 2002 provided a case of peace following a chain of failures of interventions based on the liberal peace model.

Three aspects have limited the success of liberal peace as a conflict resolution model in Africa. First is the assumed universal validity of liberal peace principles, which emphasise the protection of individual rights and disregard African traditional perspectives on family and kinship (Fischer 2000:25). The second limiting aspect is the inherent contradiction in liberal peace theory, which is applicable to inter-state wars, but not to intra-state conflicts based on identity (Nkabahona 2007). This limitation is even more pertinent in regional conflicts in which rebels and refugees take the conflict across borders, causing intricate webs of conflict relationships that are identity-based rather than interstate wars. Another internal contradiction of liberal peace is its emphasis on majoritarian democratisation which tends to ignore the role of traditional authorities and polarise identities (Fanthorpe 2006). 
The third limitation is the tendency of mediators to simplify liberal theory during implementation and the stereotyping of local contexts among mediators. Liberal peace prescriptions in African conflicts are often reduced to one or two of the three pillars, particularly democratisation and the commitment to fundamental human rights. Hence the popular adages: 'Peace and democracy are just two sides of the same coin', and 'democracies don't go to war' (Fischer 2000:1; Doyle 2004:1). While it is true that democracies are a key instrument to peace and that democracies are in most cases at peace with each other, in ethnically divided societies application of the winner-takes-all model of democracy has tended to stoke rather than prevent conflict. In a word, liberal peace has tended to ignore complex local contexts, leading to '... hastily erected "democratic" institutions vulnerable to political capture by the forces the project seeks to thwart' (Fanthorpe 2006:9). In environments where over time cultural identities have been transformed into political identities democratic elections have been fought along ethnic lines, leading to the tyranny of the majority, disaffection of the minority and intensification of identity conflicts.

The uncritical application of liberal peace in Africa has resulted in negative or cold peace based on peace agreements that settle the issue of power and 'ownership' of the state, rather than addressing the fundamental causes of conflict (Galtung 1996; Anderson 2004:106). Liberal peace models in Africa have tended to undermine the process of peace building, ending up as compromises within and between the various factions and fractions of the ethnic elite. Conflict resolution and peace making in Africa rest on the principle of power sharing but Western efforts to solve violent conflict through power sharing agreements have heavy hidden costs (Tull \& Mehler 2005:375-398). Power sharing models create 'an incentive structure would-be leaders can size upon by embarking on the insurgent path as well. As a result and irrespective of the effectiveness in any given case, power sharing agreements may contribute to the reproduction of insurgent violence' (Tull \& Mehler 2005:375). When peace agreements base power sharing and representation in government institutions on 
ethnic identity quotas, such as in Burundi, these agreements may just extend conflicts. For example, the Ethiopian federal arrangement provides for ethnically-based power sharing, yet only dominant groups benefit (Mengisteab 2007).

Liberal peace models tend to entrench a culture of impunity by not addressing injustices to civilians. 'One of the greatest shortcomings of contemporary peace processes,' argues Gawerc (2006:437), 'is that they often fail to address the bitterness including the memories and images, and the sources that generate it'.

Overcoming the limitations of liberal peace, therefore, requires frameworks that reconcile peace and justice. This results in positive peace which is comprehensive and takes into account all social levels and identities (Anderson 2004:103). It aims at creating positive conditions for reconciliation leading to comprehensive agreements and democratic institutions that empower people (Annan 1998:6, 7). Moreover it addresses the socio-economic and political conditions upon which social structures that contributed to the inequality, injustice or lack of access to social services that is leading to violent conflict, are embedded.

\section{Reconciling identity, justice and peace}

The missing link in the liberal peace model is the relationship between identity, justice and peace. While identity has a role to play in reconciliation and justice and may provide some building blocks towards the entrenchment of peace as the ultimate aim of a comprehensive conflict resolution approach, this fact has not been fully acknowledged in existing analyses (Assefa n.d.).

Justice and reconciliation imply the need for renewed inter-identity relationships, what is referred to here as reconfiguration. Rather than being the driving force in conflict, ethnic identities should be reconceived as important elements in peace building. The role of identity as an asset for 
peace building and development has already been recognised by bodies such as UNESCO (2005) and the African Union (2005).

A central aspect of the reconfiguration process is the conversion of identity from a political identity back to its roots as a cultural identity, making it less prone to violence. This reconfiguration process would ultimately involve justice and reconciliation, the final stages of conflict resolution and peace building, in which identity must play a pivotal role. The two concepts of justice and reconciliation are interrelated and interdependent: 'There can be no reconciliation without justice' (Assefa n.d.:8).

Justice has many faces: retributive justice or punishing perpetrators; restorative justice aimed at healing relations; and reparative justice designed to compensate victims (Bloomfield et al 2003:97). Identity plays a major role in restorative justice. A distinction can be drawn between incidental and structured injustice, the first referring to injustices arising from inter-personal or group relations while the latter refers to deeply embedded forms of injustice that determine overall patterns of relationship between identity groups. It is important to stress the role of structured injustice which typically takes a legalised or institutionalised form, like in the defunct apartheid system in South Africa, although non-legal forms of exclusion such as the existence of the caste system within and between identities may also constrain justice.

Resolving both structured and incidental injustices requires building institutions to entrench justice, equality and fair play. Meeting this objective may require the reconstitution of a multi-identity state as multi-identity, inclusive of ethnic and other forms of identity - class, occupation, gender, educational level and generational groups. The institutionalisation of justice demands establishing harmonious relationships between the various identities and cultures and avoiding the tendency to paralyse politics along lines of identity, particularly ethnicity (Ross 2000:1005). 
The recognition of cultural diversity as a resource in socio-economic development in UNESCO documents, and particularly the 2005 Convention on the Protection and Promotion of Diversity of Cultural Expressions, underlines its potential role in reconciliation, justice and sustainable peace. In the same vein the Charter for the Cultural Renaissance of Africa (African Union 2005) states that 'all the cultures of the world are equally entitled to respect', and 'Cultural diversity (is) a factor for mutual enrichment of peoples and nations'. Respect for cultural diversity is a useful way of depoliticising identity and promoting coexistence and interaction within society. This cosmopolitan view of identity promotes civil nationality rather than parochial ethnic nationalism. The creation of an inclusive state would foster a climate for social cohesion, building of social capital and civic citizenship. Reciprocity within the context of civic citizenship is an inherent part of sustainable peace, a fact recognised by the African Charter of Human and Peoples' Rights (An-Na'im 2002).

It is necessary to reconfigure and reconcile democracy to the reality of Africa's ethnically divided societies, in order to enable the state to become a neutral arbiter between competing identities. Integral to this process is the establishment of viable institutions including democratic constitutions, robust parliaments, and independent judiciaries (Elbadawi \& Sambanis 2000).

Justice has at least two global dimensions. First, the establishment of agreements that prevent the abuse of identity conflicts by international companies or governments. Examples are the Kimberley Process that curbs the trade in blood diamonds, and the African Union debate on a common framework on the exploitation of resources, both of which need to be urgently extended and finalised (Global Policy Forum 2006). Second, international pressure in the context of the UN Security Council has been used to force warring parties to come to the peace table. The use of political and economic sanctions by the world major powers in a unilateral fashion can undermine sustainable peace and justice. 
In addition to justice, it is widely acknowledged that reconciliation is of tremendous value in ensuring sustainable peace (Bloomfield et al 2003:12). The concept of reconciliation is broadly referred to as a new relationship between adversaries based on honest acknowledgement of the injury each party has inflicted on the other, and on apologies, forgiveness and redress, leading to new mutually enriching relationships. Reconciliation has also been understood as 'a process through which a society moves from a divided past to a shared future' (Bloomfield et al 2003). The concept connotes two major processes: the removal of underlying obstacles to peaceful coexistence between and within identity groups, and the healing of identity relations.

The first stage towards reconciliation is the demobilisation of combatants, thus providing space for the reconfiguration of their roles and relationships within a civic space. While liberal peace models give pride of place to disarmament of armed groups, it is important to extend the notion of demobilisation to the mind as a crucial step in ensuring the sustainability of peace. As the adage goes 'war begins in the mind' and by the same token peace must begin in the mind. This entails conflict transformation that seeks to broaden perceptions and social relations by creating historical awareness, and destroying myths upon which adversary identity awareness rested. Identity wars were often based on myths and perceptions that created the 'other' as an adversary, and brought about grounds for violent conflict. Conflict transformation must confront and transform these perceptions, myths and stereotypes that inform the infrastructure of war, and entrench tolerance and respect for the 'other'.

The second stage of reconciliation entails crossing identity fault-lines. Critical to this stage is the creation of awareness of the 'other' through extensive interactions with other identities to 'develop a sense of assurance that its own existence is secure' (Kelman in Ross 2000:1017). As a result individuals and identity groups will come to recognise the reality of their multiple identities as a basis of assured destiny in a civic nation (Sen 2006). 
In the 1990s, two types of instruments for reconciliation emerged in Africa: Truth and Reconciliation Commissions (TRC) and traditional reconciliation institutions. The first instrument, popularised by South Africa's experience of transition from apartheid to democracy has been extensively researched, although views about its effectiveness vary. In many instances, TRCs have restored identity relationships to a level of peaceful coexistence and even forgiveness. One of the identified shortcomings of the TRCs is blanket amnesty for perpetrators of injustice and crimes against humanity. The insistence on forgiveness has often undermined justice and created impunity (Philpott 2007).

The TRC process is based on Western individualism and thus has tended to be a crude instrument in resolving identity-based conflict. This has given rise to the wide-spread use of indigenous or traditional identitybased institutions for peace building and reconciliation. The best-known examples are the Gacaca system used in post-genocide Rwanda. Another one is the Abashingantahe (wise men) in Burundi to reconcile various warring parties. It must be noted that the African approaches to reconciliation do not necessarily stand at variance with universal values or human rights. Rather they seek to make up for the weaknesses in liberal peace models, which subordinate the community to the individual.

Where one is referring to liberal peace models or indigenous frameworks of peace making, tensions appear at two levels: between peace and justice and between reconciliation and justice. In regard to the tension between peace and justice, debates have revolved around the question of impunity. From Charles Taylor's Liberia to Kony's Lord's Resistance Army in Northern Uganda, rebels have tended to refuse making peace without impunity guarantees. This has brought into sharp focus the role of the International Criminal Court in resolving conflict. On the one hand those who call for justice call for a stronger role of the ICC, while those calling for impunity guarantees perceive it as a stumbling block to peace, a fact stressed in the Juba peace talks in Northern Uganda. 
In regard to the tension between reconciliation and justice, human rights movements have stressed retributive justice as a way of removing hatred and restoring identity relations. On their part religious groups have emphasised forgiveness as a path to a new future (Philpott 2007). In both cases the issue is a moral one, 'because of the way it conceives the relation between the individual and the group' (Crocker in Philpott 2007:8). Despite the suffering of individual members, communities often want to get on with their normal life, which requires above all peace.

The dilemma between peace, reconciliation and justice also has a regional dimension. For example, inter-state peace deals between neighbouring countries have led to the surrender of refugees and rebels to the government of their home country without an assurance of livelihood. From a global perspective international actors have tended to stress prosecution against rebels for crimes against humanity, without considering the impact of the crusade for justice, peace and stability of the state involved. Both cases highlight the need for strong regional mechanisms of reconciling peace, justice and reconciliation, and harmonising interventions by regional actors and international organisations. This demands the strengthening of the African Union's peace and security architecture, especially its mediation component including the Panel of the Wise.

Mamdani's (2001:270-276) dichotomy between 'victors' justice' and 'survivors' justice' illuminates the challenges of reconciling peace and justice. Pursuing victors' justice, he argues, would tend to reinforce the building of a Zionist type state on the ashes of conflict of genocide, a development taking place in contemporary Rwanda. On the other hand, victors' justice can simply become revenge, masquerading as justice. This, therefore, calls attention to the need for survivors' justice that does not seek to obliterate the defeated. Finally, comprehensive peace demands reconciling justice to democracy in ways that recognise the role of ethnic majorities and minorities without excluding either. 


\section{Conclusion}

The forceful resurgence of new wars that are based on identity, particularly ethnic identities, has made it imperative to revisit existing conflict resolution models with the aim of reconfiguring them. These new wars have seen the increased politicisation of ethnic identity and the polarisation of society in ways that undermine democracy, justice and peace. The politicisation of ethnicity has also intensified the weakness of the African state already beleaguered by forces of market and economic globalisation, which have everywhere undermined social citizenship. Although liberal peace models provide for the cessation of violence and initial agreements, the imperative for sustainable peace requires justice and reconciliation. We have highlighted a number of national, regional and global factors that cause and fuel identity-based conflict, and have suggested several elements of a peace-building approach that are focused on the reconfiguration of identities. The expansion of globalisation was expected to expand space for democracy and economic empowerment. It has created uncertainties, anxieties and chaotic environment which have animated parochial ethnic sensibilities and undermined civic citizenship. In a sense, the forces of globalisation have at once globalised ethnicity and localised citizenship thus creating a climate that fosters ethnic violence. A cure for localised ethnic conflict is sought in liberal peace, but liberal peace itself is limited and embroiled in internal contradictions that undermine positive peace, democracy and justice. Overcoming the limits of liberal peace demands reconfiguring frameworks of peace making to reconcile peace, justice and democracy. A place to begin is to re-conceptualise identities and cultural diversity as assets rather than obstacles in conflict resolution. Reconfiguring conflict resolution must go beyond the liberal peace orthodoxy that emphasises demobilisation as disarmament without a focus on the mind. It also demands resolving the tension between justice and peace and that between reconciliation and justice. Establishing sustainable peace also requires reconciling democracy and justice in ways that protect the rights of both majorities and minorities. At the same time, it demands striking a careful balance between 'victors' justice' 
and 'survivors' justice' in the post-conflict situation. Institutionally, the role of regional conflict resolution mechanisms is central, especially in the context of an increasing number of failed states in Africa. Finally it is important to rethink the role of international justice mechanisms, particularly the International Criminal Court, in resolving conflict in Africa. While these mechanisms have a role in resolving conflict, caution must be exercised to ensure that they do not become obstacles to lasting peace. This points to the role of traditional justice and conflict resolution mechanisms ensuring that they are aligned to universal values while at the same time addressing the cultural particularities within which identities are locked in combat. The road to sustainable peace in Africa is long and has many lanes. 'Unfortunately there is no order of priority amongst them [conflict interventions] to prescribe.... All of this must be done at once and at the same time, and the steps kept apace of each other as the process moves along... rather than as a series of discrete steps taken one step at a time' (Zartman 1995:273). Persisting on this road may again give us opportunities to celebrate identity as a building block for peaceful and sustainable societies in Africa based on multiple identities and the principle of civic nations and citizenship.

\section{Sources}

African Union 2005. Charter for the Cultural Renaissance of Africa (Draft revised). First African Union (AU) Conference of African Ministers of Culture, Nairobi, Kenya. ttt://ocpa.irmo.hr/resources/docs/AU_Cultural_Reanaissance_Charter_2005-en.pdf accessed 20 Oct 2007.

Akpan, Wilson 2007. Ethnic Diversity and Conflict in Nigeria: Lessons from the Niger Delta Crisis. African Journal on Conflict Resolution 7 (2) (this issue).

Annan, Kofi 1998. The causes of conflict and the promotion of durable peace and sustainable development in Africa: Report of the Secretary-General. http://www.un.org/ecosocdev/geninfo/sgreport/report.htm accessed 10 Aug 2006.

Anderson, R. 2004. A definition of peace. Peace and Conflict. Journal of Peace Psychology 10 (2), 101-116.

An-Na'im, A.A. 2002. Cultural transformation and human rights in Africa. London: Zed Books.

Appadurai, Arjun 1998. Dead certainty: Ethnic violence in the era of globalization. Public Culture 10 (2), 225-247. 
Arendt, Hannah 1975. The Origins of Totalitarianism. New York: Harcourt Brace.

Assefa, H. n.d. The Meaning of Reconciliation, in Global Partnership for the Prevention of Armed Conflict, People Building Peace. Utrecht: European Platform for Conflict Prevention and Transformation. http://www.gppac.net/documents/pbp/part1/2_reconc.htm accessed 29 Oct 2007.

Banégas, R. 2006. Côte d'Ivoire: Patriotism, ethnonationalism and other African modes of self-writing. African Affairs 105 (421), 535-552

Bayart, J-F. 1993. The state in Africa: The politics of the belly. London: Longmans.

Bayart, J-F. 2005. The illusion of cultural identity. London: Hurst \& Company.

Berman, B.J. 1998. Ethnicity, patronage and the African state: the politics of uncivil nationalism. African Affairs 97 (388), 305-341.

Biaya, T.K. 2001. Parallel society in the Democratic Republic of Congo, in Bekker, S., Dodds, M. \& Khosa, M.M., Shifting African identities. Vol. II in the series: Identity? Theory, Politics, History, 43-60. Pretoria: Human Sciences Research Council.

Bloomfield, D., Barnes, T. \& Huyse, L. 2003. Reconciliation after Violent Conflict: A Handbook. Stockholm: International Institute for Democracy and Electoral Assistance. http://www.idea.int/publications/reconciliation/upload/reconciliation_full.pdf accessed 29 Oct 2007.

Braathen, E., Bøås, M. \& Sæter, G. 2000. Ethnicity kills? The politics of war, peace and ethnicity in SubSaharan Africa. International Political Economy Series. London: Macmillan.

Broch-Due, V. 2005. Violence and belonging: Analytical reflections, in Broch-Due, V. (ed) 2005, Violence and belonging: the quest for identity in post-colonial Africa,1-40. London: Routledge.

Collier, P. \& Sambanis, N. 2005. Understanding civil war: Evidence and analysis. Vol. 1: Africa. Washington: World Bank.

Deng, B. 2005. The challenge of cultural, ethnic and religious diversity in peacebuilding and constitution-making in post-conflict Sudan. Civil wars 7 (3), 258-269.

Doyle, M.W. 2004. Liberal internationalism: peace, war and democracy. Nobel Prize Organisation. http:/nobelprize.org/nobel_prizes/peace/articles/doyle/index.html accessed 22 Oct 2007.

Doyle, M.W. 2005. Three pillars of the liberal peace. American Political Science Review 99 (3), 463-466.

Ekeh, Peter P. 1975. Colonialism and the two publics in Africa: a theoretical statement. Comparative studies in society and history 17 (1), 91-112.

Elbadawi, I. \& Sambanis, N. 2000. Why are there so many civil wars in Africa? Understanding and preventing violent conflict. Journal of African Economies 9 (3), 244-269.

El-Battahani, Atta 2007. Tunnel Vision or Kaleidoscope: Competing Concepts on Sudan Identity and National Integration. African Journal on Conflict Resolution 7 (2) (this issue). 
Endalew, T. 2002. Conflict Resolution through Cultural Tolerance: An Analysis of the Michu Institution in Metekkel Region, Ethiopia. Social Science Research Report Series, no. 25. Addis Ababa: OSSREA.

Eyo, D. 1999. Community, citizenship and the politics of ethnicity in post-colonial Africa, in Kalipeni, E. \& Zeleza, P. (eds), Sacred spaces and public quarrels. Trenton NJ: Africa World Press.

Fanon, Frantz 1967. The wretched of the world. London: Penguin.

Fanthorpe, R. 2006. On the limits of liberal peace: Chiefs and democratic decentralization in post-war Sierra Leone. African Affairs 105 (418), 27-49.

Fearon, J.D. \& Laitin, D.D. 2003. Ethnicity, insurgency and civil war. American Political Science Review 97 (1), 75-90.

Fischer, M. 2000. The liberal peace: ethical, historical, and philosophical aspects. BCSIA Discussion Paper 2000-7. Kennedy School of Government, Harvard University.

Galtung, J. 1996. Peace by peaceful means: peace and conflict, development and civilization. Oslo: International Peace Research Institute.

Gawerc, M.I. 2006. Peace-building: Theoretical and concrete perspectives. Peace \& Change 31 (4), 435-478.

Global Policy Forum 2006. General Assembly Backs Kimberley Process to Prevent Diamonds from Funding Conflict. UN News.

http://www.globalpolicy.org/security/natres/diamonds/2006/1204gaback.htm accessed10 Sep 2007.

Horowitz, D.L. 1985. Ethnic groups in conflict. Berkeley: University of California Press.

Huntington, S.P. 1996. The clash of civilizations and the remaking of world order. New York: Simon \& Schuster.

IANSA/Oxfam 2007. Africa's mission billions: International arms flow and the cost of conflict. Briefing paper 107. Oxford: Oxfam.

http://www.oxfam.org/en/files/bp107_africas_missing_billions_0710.pdf/download accessed 10 Nov 2007.

Kagwanja, P. 2001. Politics of marionettes: Extra-legal violence and the 1997 elections in Kenya, in Rutten, M., Mazrui, A. \& Grignon, F. (eds) Out for the count: The 1997 general elections and prospects for democracy in Kenya. Kampala: Fountain Publishers.

Kagwanja, P. 2003. Globalizing Ethnicity, Localizing Citizenship: Globalization, Identity Politics and Violence in Kenya's Tana River Region, Africa Development 28 (1\&2), 112-152.

Kagwanja, P. 2007. South Africa and peacemaking in Africa: Closing the capacity gap. Draft occasional paper. Pretoria: Human Sciences Research Council.

Kagwanja, P. \& Ntegeye, G. (rapporteurs) 2001. Regional Conflict Formations in the Great Lakes Region of Africa: Structure, Dynamics and Challenges for Policy. Report of the Conference organized by Center for International Cooperation, New York University, November 2001. 


\section{Gerard Hagg and Peter Kagwanja}

Kaldor, Mary 1999. New Wars and Old Wars: Organized Violence in a Global Era. Cambridge: Polity Press.

Khazanov, A.M. et al 2004. Priorities for research on culture, identity, and conflict, in Committee on conflict and resolution in multiethnic societies. 2004. Conflict and reconstruction in multiethnic societies: Proceedings of a Russian-American workshop. Washington: National Academies Press. http://www.nap.edu

Lonsdale, J. 1994. Moral ethnicity and political tribalism, in Kaarsholm, P. \& Hultin, J. (eds), Inventions and boundaries: Historical and anthropological approaches to the study of ethnicity and nationalism. Roskilde: Roskilde University Press.

Mamdani, M. 1996. Citizen and Subject: Contemporary Africa and the Legacy of Late Colonialism. Princeton, N.J.: Princeton University Press.

Mamdani, M. 2001. When Victims become killers: Colonialism, Nativism and the Genocide in Rwanda. Princeton, N.J.: Princeton University Press.

Mamdani, M. 2002. Making sense of political violence in postcolonial Africa. Identity, Culture and Politics 3 (2), 1-24.

Mengisteab, Kidane 2007. Identity Politics, Democratisation and State Building in Ethiopia's Federal Arrangement. African Journal on Conflict Resolution 7 (2) (this issue).

Nkabahona, A. 2007. Healing the wounds of conflict through reconciliation: The African paradigm. Fourth IIPT African conference. International Institute for Peace through Tourism. http://www.iipt.org/africa2007/PDFs/AlexNkabahona.pdf accessed 29 Nov 2007.

Organisation of African Unity 1975. Cultural Charter for Africa. Online available: http://ocpa.irmo.hr/resources/docs/Cultural_Charter-en.pdf accessed 2 Nov 2007.

Osman, Abdulahi 2007. Cultural Diversity and the Somali Conflict: Myth or Reality? African Journal on Conflict Resolution 7 (2) (this issue).

Philpott, D. 2007. Religion, reconciliation, and transitional justice: The state of the field. SSRC Working Papers. New York: Social Science Research Council.

Prah, K.K. 2004. African wars and ethnic conflicts - rebuilding failed states. Occasional Paper: Human Development Report 2004. New York: UNDP.

Prunier, G. 1997. The Rwanda crisis: History of a genocide. New York: Columbia University Press.

Richards, P. 2005. New war: An ethnographic approach, in Richards, P. (ed), No peace no war, 1-21. Athens: Ohio University Press.

Ross, M.H. 2000. Creating the conditions for peacemaking: theories of practice in ethnic conflict resolution. Ethnic and racial studies 23 (6), 1002-1034.

Rubin, B.R. 2006. Central Asia and Central Africa: Transnational wars and ethnic conflicts. Journal of Human Development 7 (1), 5-22.

Salih, M. 1989. New wine in old bottles: Tribal militias and the Sudanese state. Review of African Political Economy 45-46,168-174.

Sen, A. 2006. Identity and violence. New York: WW Norton. 
Storey, Andy 1999. Globalization and the African State. Trocaire Development Review, pp.39-56.

Tan, L. 2006. A blueprint for change: Diversity as a civic asset. Washington: Partners for Livable Communities.

Tull, D. \& Mehler, A. 2005. The hidden costs of power-sharing: Reproducing insurgent violence in Africa. African Affairs 104 (416), 75-98. http://afraf.oxfordjournals.org/cgi/content/abstract/106/422/1 accessed 29 Oct 2007.

UNESCO 2005. Convention on the protection and promotion of diversity of cultural expressions. Paris: UNESCO.

United Nations University 2007. Examining the Shortcomings of 'Liberal peace model'. UNU.UNU.edu.Update Issue 46. June-August. http://UNU,unu.edu/issue46_25.htm accessed 22 Nov 2007.

Young, Crawford 2004. The End of the Post-Colonial State in Africa? Reflections on Changing African Political Dynamics. African Affairs 103, 23-49.

Zartman, I.W. 1995. Putting things back again, in Zartman, I.W. (Ed.) Collapsed states: The disintegration and restoration of legitimate authority. SAIS African Studies Series. Colorado: Lynne Rienner. 
